\title{
Molecular characterization of a decapod Penstylidensovirus I (PstDVI) isolated from Penaeus semisulcatus in Egypt
}

\begin{abstract}
This study demonstrates the existence of decapod Penstylidensovirus 1 (PstDV1), in P.semisulcatus in Dibah Triangle Zone (DTZ), Egypt. The prevalence of infectious was studied in post larvae and juveniles at hatchery and farm levels. A survey of the PstDV1 prevalence in $P$. semisulcatus was undertaken in commercial shrimp hatcheries and farms, using polymerase chain reaction (PCR) to amplify a fragment of PstDV1, which encompasses the coding sequence for one of the viral coat proteins. The results showed that PstDV1 virus was responsible on high mortalities and deformity in the P. semisulcatus. The PCR screening of PstDV1 infection in shrimp hatcheries and farms allowed rejection of infected broodstock and postlarvae. The prevalence of PstDV-1 was high in all hatcheries and grow-out ponds surveyed, indicating that the virus was prevalent in aquaculture facilities at DTZ with statistically significant samples. This study recommends strict biosecurity measures are advisable for the continuity of P.semisulcatus culture in Egypt.
\end{abstract}

Volume 8 Issue 6 - 2019

\author{
Mohamed E Megahed, Mohamed Fathi \\ National Institute of Oceanography and Fisheries (NIOF), Egypt
}

Correspondence: Mohamed E Megahed, National Institute of Oceanography and Fisheries (NIOF), Gulfs of Suez \& Aqaba's Branch, Egypt, Email aquagaimprove@gmail.com

Received: November 0I, 2019 | Published: November 15, 2019

Keywords: Penaeus semisulcatus, IHHNV, stunted growth, farm, hatchery

\section{Introduction}

As shrimp aquaculture in Egypt has evolved from a subsistent farming activity in the early 1980 s to an economically important global industry in the early 2010. Penaeid shrimp farming is becoming an important industry in Egypt in its developmental goals. Currently, the shrimp industry is based mainly on the culture of introduced pacific white shrimp, Litopenaeus vannamei. Egypt seeks to be a big shrimp producer in the near future. Disease has had a major impact on shrimp aquaculture in Egypt since it became a significant commercial entity in the early 2010. Viral diseases have also evolved to become a serious threat to the sustainable growth of shrimp industry. Many practices have been used by shrimp farmers in Egypt to manage many of the viral, bacterial, fungal and protozoan diseases using chemotherapeutics. However, most diseases such as viral diseases have been more difficult to manage and they have been responsible for the mass mortalities and socioeconomic impacts to shrimp farmers. Five of the seven virus diseases of penaeid shrimp listed by the World Animal Organization (OIE), have become enzootic in Egypt following the introduction of both Fenneropenaeus indicus and L.vannamei between 2010 and 2015. Examples include the white spot syndrome virus (WSSV) (KR083866), Penaeus stylirostrisdensovirus 1 (PstDNV1) (KT316249.1, KT316250.1, KT316251.1, KT316252.1, KT316253.1, KT316254.1, KT316256.1, KT316257.1, KT316258.1, KT316259.1 and KT316260.1), hepatopancreatic parvovirus (HPV) (KR492908.1，KR492909.1，KR4929010.1，KR492911.1, KT316240.1, KT316241.1, KT316242.1, KT316243.1, KT316244.1 and KT316245.1), yellow head virus (YHV) (KT316278.1), and gillassociated virus (GAV) (KT316279.1).

IHHNV was classified as Penaeus stylirostris densovirus (PstDNV) in the family Parvoviridae, sub-family Densovirinae. ${ }^{1} \mathrm{IHHNV}$ is an icosahedral, non-enveloped parvovirus with a single-stranded, $4.1 \mathrm{~kb}$ DNA genome comprised of 3 large open reading frames (ORF). ${ }^{2}$ It is the smallest penaeid shrimp virus, with non enveloped and icosahedral virions averaging $22-23 \mathrm{~nm}$ in diameter. ${ }^{2,3} \mathrm{IHHNV} / P$ stDV-1 genome is comprised of 3 large open reading frames, the left ORFs 1 and 2 that codifies non structural proteins and the right OFR 3 that codifies the viral capsid protein. ${ }^{2}$ The disease IHHNV/PstDV-1 and its causative agent, IHHNV/PstDV-1, were first described in the early $1980 \mathrm{~s}$, as the cause of acute epizootics and mass mortality in blue shrimp (Litopenaeus stylirostris) farmed in super intensive raceway systems in Hawaii, causing acute epizootics and mass mortalities, ${ }^{4,5}$ in North, South, and Central America, Caribbean and the Indo-Pacific, ${ }^{6,7}$ in Brazil $^{8}$ and the Philippines ${ }^{9,10,11}$ and Indian and South-East Asia. ${ }^{12}$

To date, eight complete genome sequences of IHHNV/PstDV-1 are available in GenBank. Genomes and complete coding sequences from other parts of the globe such as China, Egypt, Hawaii, India, Korea, Mexico, Vietnam, Taiwan, Thailand, Philippines and Indonesia are available. This virus caused deformity, reduced growth, small sized shrimps at harvest, abdominal anomalies and curly antennae, cuticular and rostrum deformities in Penaeus semisulcatus and F. indicus in Egypt from 1980 till 2015, which typically agree with results from previous studies in the literature. ${ }^{13,14}$

The aim of this study was to develop a routine monitoring program for IHHNV/PstDV-1 diagnosis and establish a biosecurity management plan in shrimp farms and hatcheries.

\section{Materials and methods}

\section{Sample collection}

P. semisulcatus were collected from shrimp ponds at Dibah Triangle Zone (DTZ) (Figure 1) between 2015 and 2016. Samples were collected directly from the ponds and processed at the pond site for different analysis. Samples for histopathology were immediately fixed in Davidson's fixative as described by Bell and Lightner. ${ }^{13}$ For PCR analyses, pleopod was collected in 90\% ethyl alcohol. All samples were transported to laboratory for further analysis. A total of 358 samples were evaluated, among which 261 were with reduced growth appearance and IHHNV/PstDV-1 -positive. The IHHNV/ 
PstDV-1 -positive shrimp showed clinical signs of run deformity disease (RDS). The specimens were transported live and individually examined to the laboratory and the diagnosis was confirmed using conventional PCR methods. ${ }^{12}$

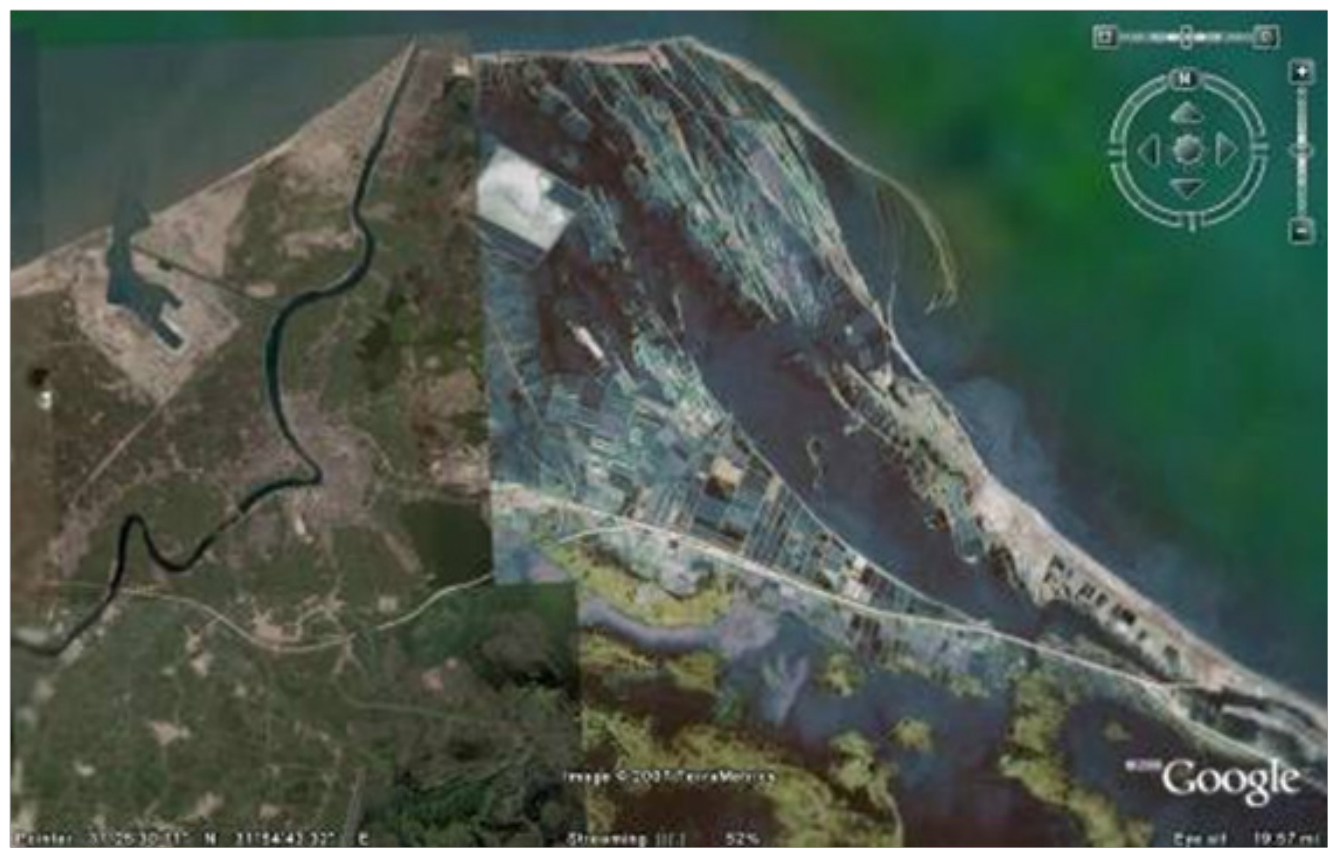

A

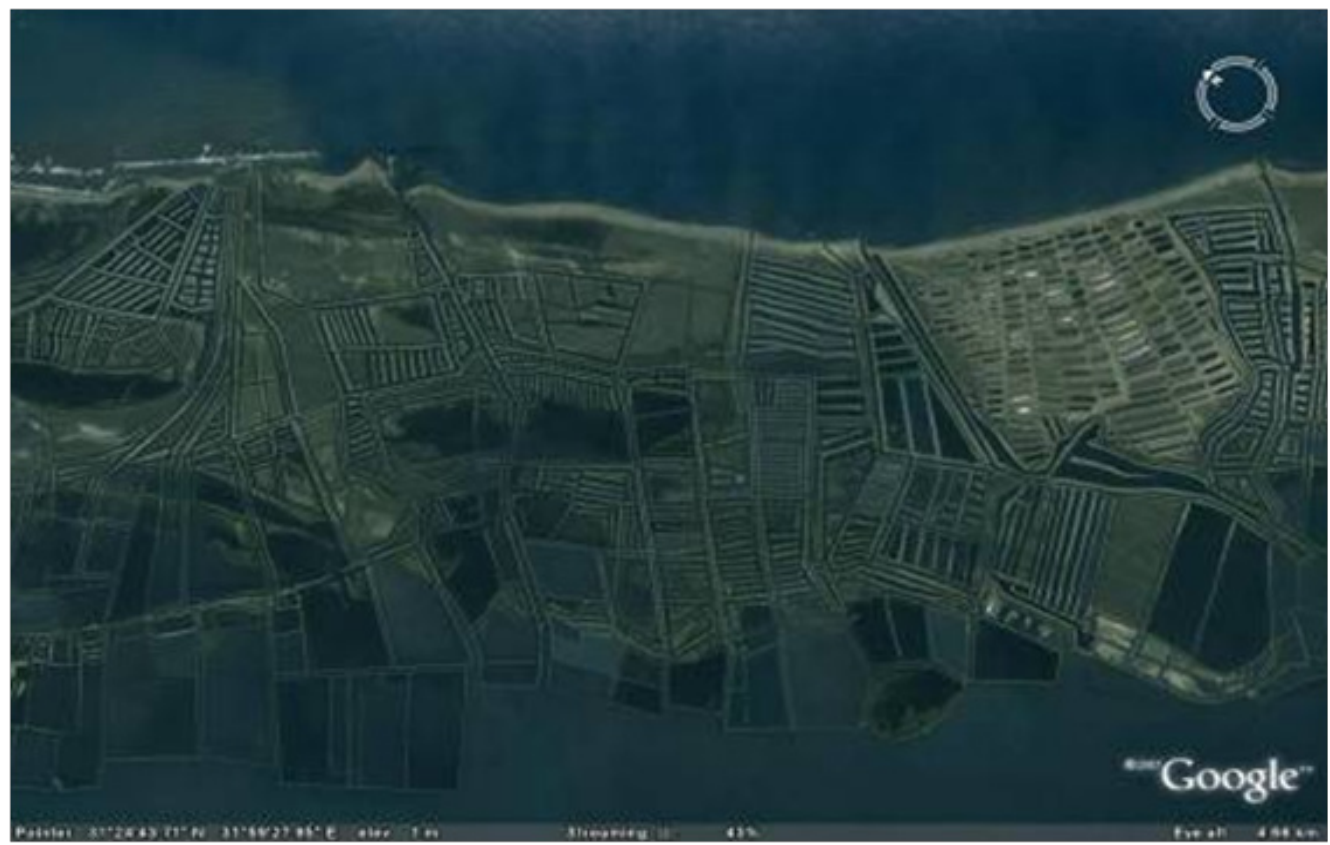

B

Figure I The study site. (A) Dibah Triangle Zone (DTZ) farming site. (B) Studied farm.

\section{Observation of shrimp health at harvest \& Fry analysis at the hatchery}

\section{histopathology}

This study developed some parameters as indicators for postlarvae analysis and shrimp health observations at hatchery and farm levels.
The shrimp postlarvae (PL) of age PL19 were evaluated at the hatchery for health status and quality using appropriate parameters (Table 1-2). The parameters developed to include the gut, muscle, gill, rostrum and appendages of the shrimp PLs. Health indicator 
parameters were checked such as; Degree of Infection (DOi); Swollen Hind Gut (SHG); Gut Necrosis (GN); Muscle Necrosis (MN); Gut to Muscle Ratio (GMR); Protozoan Infection (PI); Filamentous
Bacterial Infection (FBi); Rostral Spine (RS); Rostral Necrosis (RN); and Necrosis per Animal (N)

Table I Health and quality parameters of shrimp postlarvae (PL) at the hatchery stage before stocking

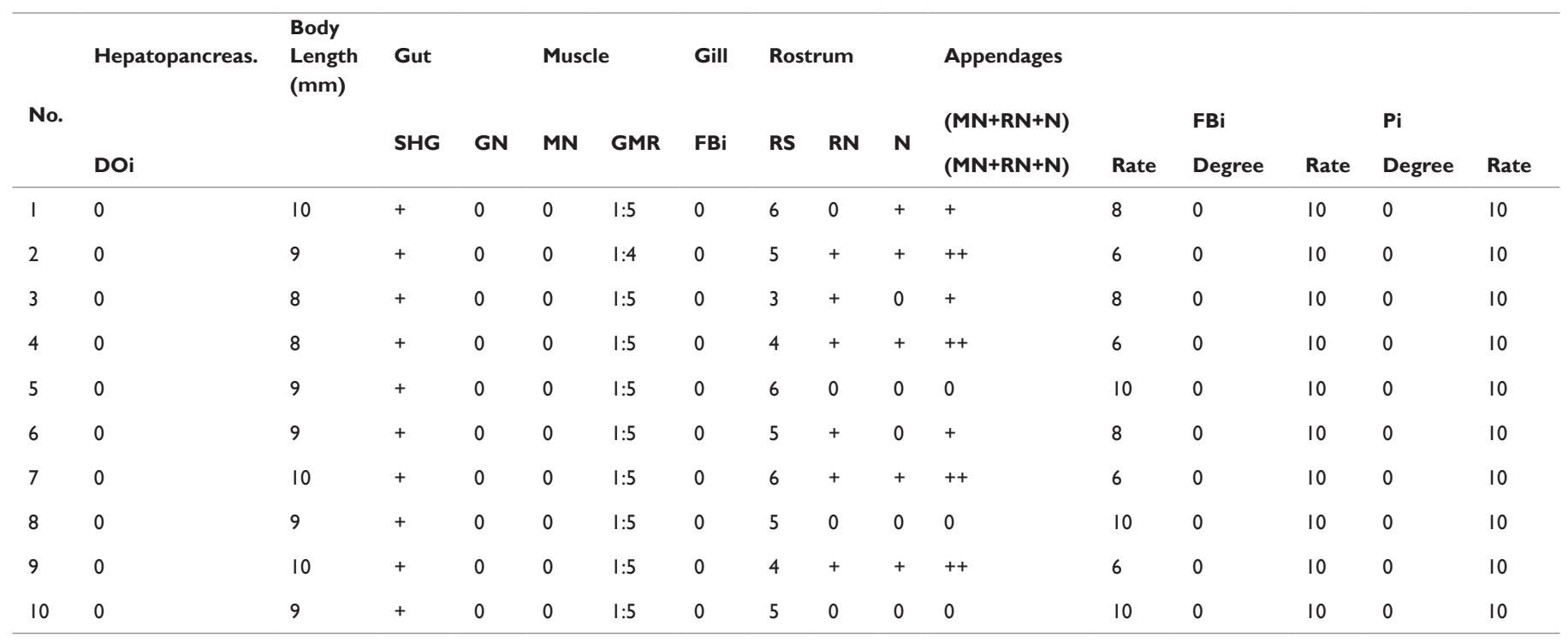

PL's Age: PLI 9

Doi, Degree of Infection; SHG, Swollen Hind Gut; GN, Gut Necrosis; MN, Muscle Necrosis; GMR, Gut to Muscle Ratio; FBi, Filamentous Bacterial Infection; PI, Protozoan Infection; RS, Rostral Spine; RN, Rostral Necrosis; N,Necrosis per Animal

Table 2 Observation of shrimp health at harvest

\begin{tabular}{|c|c|c|c|c|c|c|c|c|c|c|c|c|c|c|}
\hline ID & $\begin{array}{l}\text { Gut } \\
\text { Status }\end{array}$ & $\begin{array}{l}\text { Gut } \\
\text { Color }\end{array}$ & $\begin{array}{l}\text { Necrosis } \\
\text { Tail }\end{array}$ & $\begin{array}{l}\text { Necrosis } \\
\text { Rostrum }\end{array}$ & $\begin{array}{l}\text { Necrosis } \\
\text { Appen- } \\
\text { dages }\end{array}$ & $\begin{array}{l}\text { An- } \\
\text { tennal } \\
\text { Cut }\end{array}$ & $\begin{array}{l}\text { Hepato- } \\
\text { pancreas } \\
\text { Color }\end{array}$ & $\begin{array}{l}\text { Loose } \\
\text { Shell }\end{array}$ & $\begin{array}{l}\text { Gill } \\
\text { Fila- } \\
\text { men- } \\
\text { tous }\end{array}$ & $\begin{array}{l}\text { Gill } \\
\text { Proto- } \\
\text { zoan }\end{array}$ & $\begin{array}{l}\text { Gill } \\
\text { Dead } \\
\text { Algae }\end{array}$ & $\begin{array}{l}\text { Appen- } \\
\text { dages } \\
\text { Fila- } \\
\text { men- } \\
\text { tous }\end{array}$ & $\begin{array}{l}\text { Appen- } \\
\text { dages } \\
\text { Proto- } \\
\text { zoan }\end{array}$ & $\begin{array}{l}\text { Appen- } \\
\text { dages } \\
\text { Dead } \\
\text { Algae }\end{array}$ \\
\hline I & Full & Brown & Nil & Nil & Nil & Nil & Brown & Nil & Nil & Nil & Nil & Nil & Nil & Nil \\
\hline 2 & Full & Brown & Nil & Nil & Nil & Nil & Brown & Nil & Nil & Nil & + & Nil & Nil & + \\
\hline 3 & Half & Brown & Nil & Nil & Nil & Nil & Brown & Nil & Nil & Nil & Nil & Nil & Nil & Nil \\
\hline 4 & Full & Brown & Nil & Nil & Nil & Nil & Brown & Nil & Nil & Nil & + & Nil & Nil & + \\
\hline 5 & Full & Brown & Nil & Nil & Nil & Nil & Brown & Nil & Nil & Nil & Nil & Nil & Nil & Nil \\
\hline 6 & Full & Brown & Nil & Nil & Nil & Nil & Brown & Nil & Nil & Nil & Nil & Nil & Nil & Nil \\
\hline 7 & Full & Brown & Nil & Nil & Nil & Nil & Brown & Nil & Nil & Nil & Nil & Nil & Nil & Nil \\
\hline 8 & Full & Brown & Nil & Nil & Nil & Nil & Brown & Nil & Nil & Nil & Nil & Nil & Nil & Nil \\
\hline 9 & Full & Brown & Nil & Nil & Nil & Nil & Brown & Nil & Nil & Nil & Nil & Nil & Nil & + \\
\hline 10 & Full & Brown & Nil & Nil & Nil & Nil & Brown & Nil & Nil & Nil & Nil & Nil & Nil & Nil \\
\hline 11 & Full & Brown & Nil & Nil & Nil & Nil & Brown & Nil & Nil & Nil & Nil & Nil & Nil & Nil \\
\hline 12 & Half & Brown & Nil & Nil & Nil & Nil & Brown & Nil & Nil & Nil & Nil & Nil & Nil & Nil \\
\hline 13 & Full & Brown & Nil & Nil & Nil & Nil & Brown & Nil & Nil & Nil & Nil & Nil & Nil & Nil \\
\hline 14 & Full & Brown & Nil & Nil & Nil & Nil & Brown & Nil & Nil & Nil & Nil & Nil & Nil & Nil \\
\hline 15 & Full & Brown & Nil & Nil & Nil & Nil & Brown & Nil & Nil & Nil & Nil & Nil & Nil & Nil \\
\hline 16 & Full & Brown & Nil & Nil & Nil & Nil & Brown & Nil & Nil & Nil & Nil & Nil & Nil & Nil \\
\hline 17 & Full & Brown & Nil & Nil & Nil & Nil & Brown & Nil & Nil & Nil & Nil & Nil & Nil & Nil \\
\hline 18 & Full & Brown & Nil & Nil & Nil & Nil & Brown & Nil & Nil & Nil & Nil & Nil & Nil & Nil \\
\hline 19 & Full & Brown & Nil & Nil & Nil & Nil & Brown & Nil & Nil & Nil & Nil & Nil & Nil & + \\
\hline 20 & Full & Brown & Nil & Nil & Nil & Nil & Brown & Nil & Nil & Nil & + & Nil & $\mathrm{Nil}$ & + \\
\hline
\end{tabular}




\section{Observation of shrimp health at harvest}

Health status parameters developed for estimation of the shrimp health status at the farm level were: gut status, gut color, necrosis tail, necrosis rostrum, necrosis appendages, antennal gut, hepatopancreas color, loose shell, gill filamentous, gill protozoan, gill dead algae, appendages filamentous, appendages protozoan, and appendage dead algae.

\section{Detection of IHHNVIPstDV-I and other potential viruses by PCR}

Details for shrimp samples used in PCR analysis were included in Table 3. Total DNA was extracted from the pleopods of each shrimp using the QiaAmp DNA mini kit (Qiagen) following manufacturer's protocols. DNA from each specimen was then amplified via PCR using the primer pair IHHNV648F (GAACGGCTTTCGTATTTTGG), and IHHNV648R (AGCGTAGGACTTGCCGATTA). ${ }^{12}$ After the first reaction, each reaction products were used as templates in the nested PCR, in which were used primers IHHNV648F and IHHNV648R. The PCR protocol followed was: pre-denaturation at $95^{\circ} \mathrm{C}$ for 15 minutes, followed by 35 denaturation cycles at $94^{\circ} \mathrm{C}$ for 30 seconds, annealing at $59^{\circ} \mathrm{C}$ for 1 minute 30 seconds, extension at $72^{\circ} \mathrm{C}$ for 1 minute 30 seconds, and final extension at $72^{\circ} \mathrm{C}$ for 10 minutes. Total volume of each PCR mix was $25 \mu \mathrm{L}$, consisting of Master Mix $12.5 \mu \mathrm{L}$, Primer mix $2.5 \mu \mathrm{L}$, Q-solution $2.5 \mu \mathrm{L}$, and DNA Template $2.0 \mu \mathrm{L}$, with $5.5 \mu \mathrm{L}$ of nuclease free water to make up the desired reaction volume. The results from electrophoresis of the PCR products, on $1.5 \%$ agarose gel with $1 \% \mathrm{TE}$ electrophoresis buffer stained with Ethidium bromide, were examined and photographed. Other viruses such as WSSV, YHV and TSV were screened according to. ${ }^{6}$

Table 3 Sample details and PCR analysis of shrimp samples from different farms of Dibah Triangle Zone, Egypt

\begin{tabular}{|c|c|c|c|c|c|c|c|c|c|c|c|}
\hline \multirow{2}{*}{$\begin{array}{l}\text { Farm } \\
\text { number }\end{array}$} & \multirow{2}{*}{$\begin{array}{l}\text { Sampling } \\
\text { number }^{\mathrm{a}}\end{array}$} & \multirow{2}{*}{$\begin{array}{l}\text { DOC at } \\
\text { Sampling }\end{array}$} & \multicolumn{2}{|c|}{ WSSV } & \multicolumn{2}{|c|}{ IHHNV/PstDV-I } & \multicolumn{2}{|l|}{ YHV } & \multicolumn{2}{|l|}{ TSV } & \multirow{2}{*}{$\begin{array}{l}\text { DOC at } \\
\text { harvest }\end{array}$} \\
\hline & & & $\begin{array}{l}\text { I } \\
\text { Step }\end{array}$ & $\begin{array}{l}\text { II } \\
\text { Step }\end{array}$ & I Step & II Step & $\begin{array}{l}\text { I } \\
\text { Step }\end{array}$ & $\begin{array}{l}\text { II } \\
\text { Step }\end{array}$ & $\begin{array}{l}\text { I } \\
\text { Step }\end{array}$ & $\begin{array}{l}\text { II } \\
\text { Step }\end{array}$ & \\
\hline \multirow{3}{*}{ Farm I } & 1 & 27 & - & + & + & + & - & - & - & - & \multirow{3}{*}{50} \\
\hline & 2 & 50 & - & - & + & + & - & - & - & - & \\
\hline & $\mathrm{I}$ & 27 & - & + & + & + & - & - & - & - & \\
\hline \multirow{6}{*}{ Farm 2} & $\mathrm{I}$ & 64 & + & + & - & - & - & - & - & - & 64 \\
\hline & I & 55 & - & - & - & - & - & - & - & - & \multirow[t]{2}{*}{68} \\
\hline & 2 & 65 & - & + & + & + & - & - & - & - & \\
\hline & 1 & 57 & - & + & + & + & - & - & - & - & 60 \\
\hline & 1 & 39 & + & + & - & + & - & - & - & - & \multirow{2}{*}{57} \\
\hline & 2 & 57 & + & + & + & + & - & - & - & - & \\
\hline
\end{tabular}

DOC days of culture

${ }^{\mathrm{a} E a c h}$ sampling included 3 samples from a particular pond.

\section{Results}

\section{Fry analysis summary}

Table 1 present the results of health status parameters of shrimp PL at the hatchery. The results showed that the PL19 at the hatchery before farm stocking are characterized by acceptable quality and normal health status with no symptoms of disease infection.

\section{Observation of shrimp health at harvest}

Field observations of the shrimp at the grow out ponds indicated normal quality parameters, by observing the gut status, gut color, necrosis tail, necrosis rostrum, necrosis appendages, antennal gut, hepatopancreas color, loose shell, gill filamentous, gill protozoan, gill dead algae, appendages filamentous, appendages protozoan, and appendage dead algae (Table 2). This shows that it is necessary to include PCR test for conformation the health status of the shrimp $\mathrm{PL}$ at the hatchery and regular monitoring of the health status of the shrimp during the grow out period.

\section{IHHNVIPstDV-I gross signs in P.semisulcatus}

IHHNV/PstDV-1 caused retardation in growth and smaller size at harvest in juveniles and adults of P.semisulcatus. Infected shrimp with acute IHHNV/PstDV-1 showed reduction in food consumption, become too weak and cannibalized by healthier shrimp. Infected $P$. semisulcatus have a mottled appearance (Figure 2).

\section{Histopathology of IHHNVIPstDV-I infections}

The Cowdry type A inclusion bodies are eosinophilic and appear as, intranuclear inclusion bodies within chromatin-marginated, hypertrophied nuclei of cells in tissues of ectodermal and mesodermal origin. Cowdry type A inclusion bodies in gill sections of affected shrimps, suggestive of IHHNV/PstDV-1 infection were also observed (Figure 3). Histopathology and PCR analysis, clearly showed that the mortality of the shrimp was caused by either IHHNV/PstDV-1 alone or it was a combined effect of both WSSV and IHHNV/PstDV-1.

\section{PCR amplification and prevalence of IHHNVIPstDV-I infection and other potential viruses}

PstDV-1 presence or absence was determined through PCR amplification using the primer pair IHHNV648F, and IHHNV648R on all samples, producing a 300-350bp PCR product. Samples from all the farms that were included in this study were found to have different degrees of IHHNV/PstDV-1 infection and were detected by PCR (Figure 4). High prevalence of IHHNV/PstDV-1 was also 
observed in different samples analyzed for this study. Overall, $85.47 \%$ of the samples analyzed were positive for were positive in the $1^{\text {st }}$ step indicating high load of the virus and only $14.53 \%$ were negative for WSSV. Due early mortality of IHHNV/PstDV-1 P.semisulcatus all the farms were harvested with a low DOC. This is as evidenced by the PCR analysis (Figure 4). The control shrimp IHHNV/PstDV-1 infection free is shown in Figure 5.

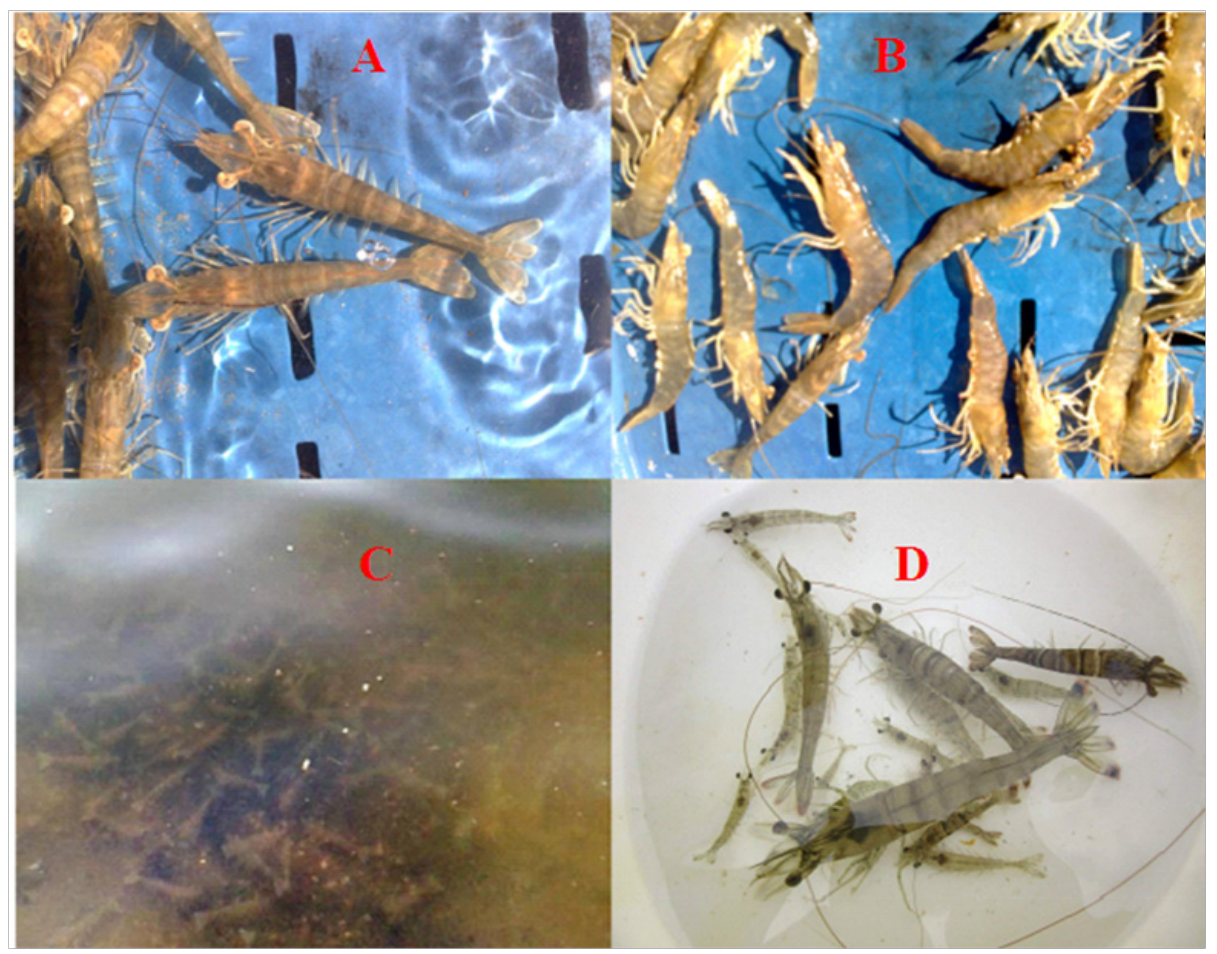

Figure 2 (A) Small sized shrimp with bent rostrums and the antennal flagella are wrinkled, brittle and broken-off. (B) Color of dead shrimp change to white and blue. (C) Shrimp P. semisulcatus underwater in the pond with cannibalistic behavior and nervous behavior. D) Infected IHHNV/PstDV-I Penaeus semisulcatus showing size variation.
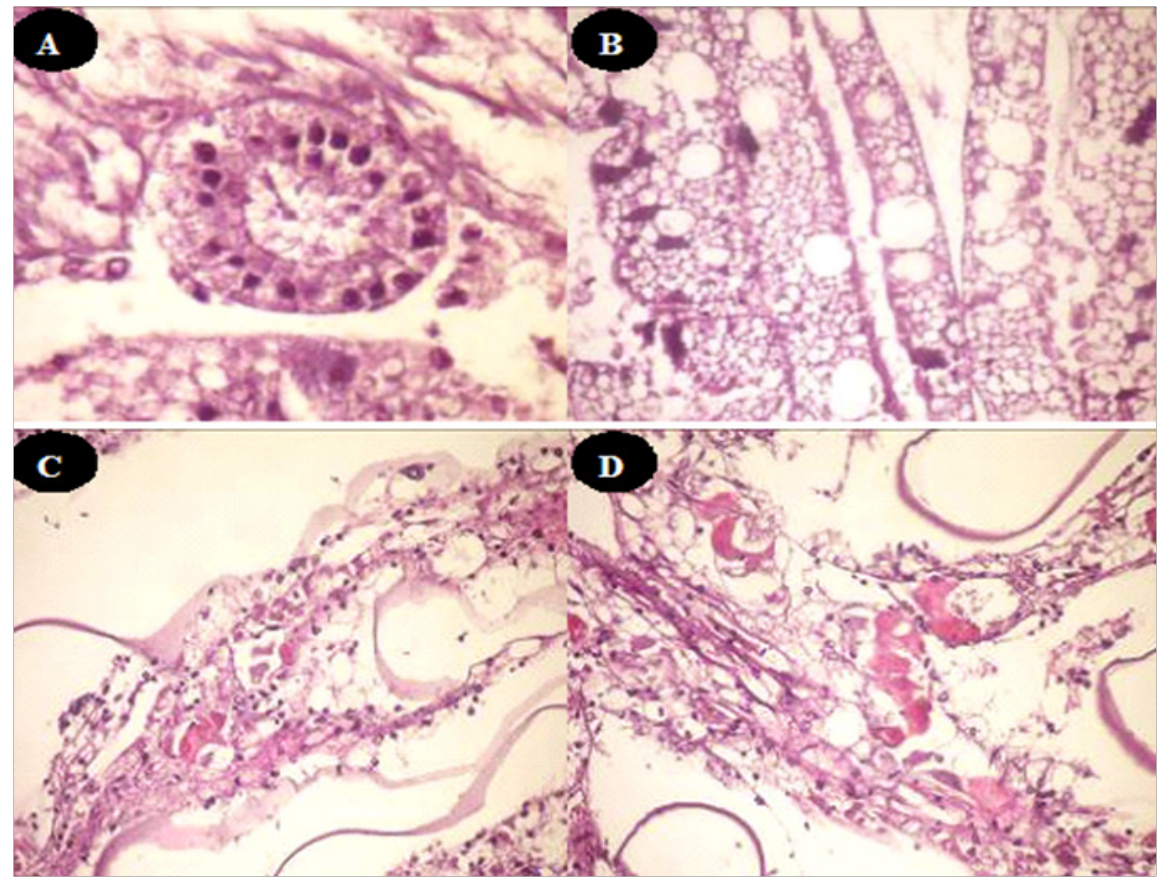

Figure 3 Histopathology of IHHN in P.semisulcatus is shown in H\&E stained sections. (A) Shrimp ovary: the stroma was thick associated with multiple numbers of immature follicles. (B) Gills: the filaments showed ischaemia allover the arch. (C-D) Anterior gut: there was diffuse necrosis in the mucosal layer as well as the underlying musculature and diffuse necrosis in the mucosal layer as well as the underlying musculature. All tissues showing intranuclear, haloed, eosinophilic Cowdry type $\mathrm{A}(\mathrm{CAl})$ inclusion bodies. 


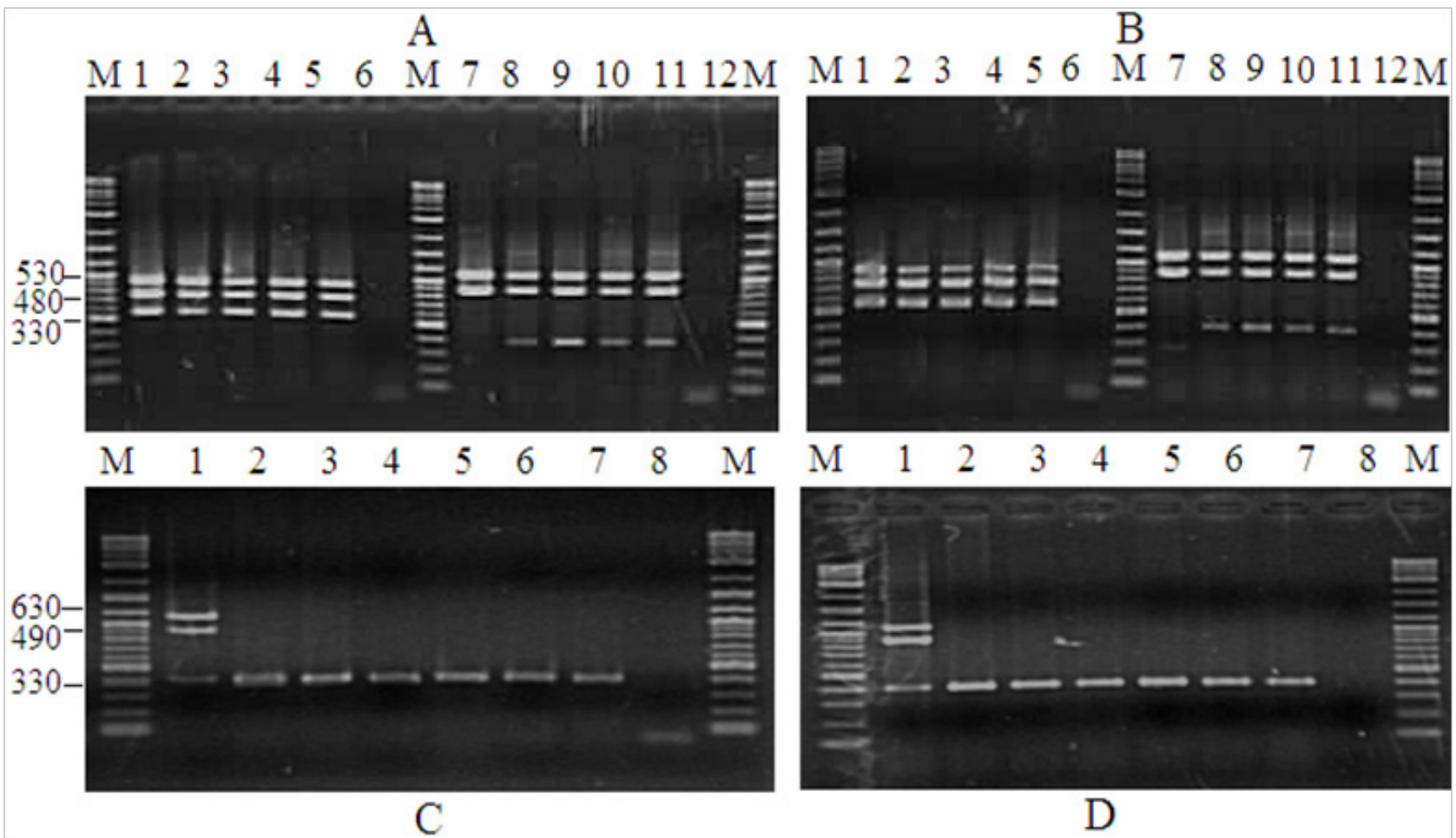

Figure 4 Detection of PstDNV I is P. semisulcatus by PCR. Agarose gel showing PCR amplification using nested PCR primers. A-B) Lane M: Molecular weight marker (I00 bP); Lane I-5 and 7-II: I-step PCR positive control; Lane 2: Negative control; Lanes 6 and I2: Negative control. C-D) IHHNV infected samples by nested PCR. Lane M: Molecular weight marker (I00 bp); Lane 2: IHHNV positive control sample. Lane 8 IHHNV negative control sample.

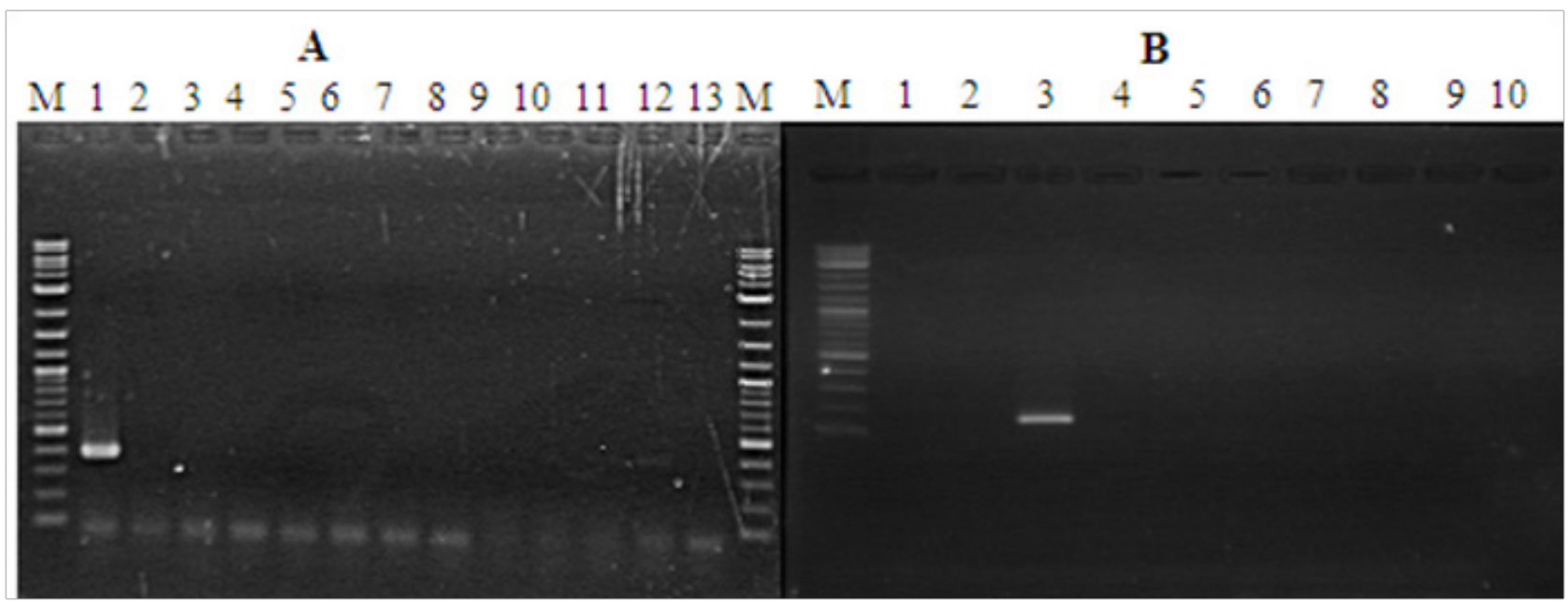

Figure 5 Detection of PstDNV I in control shrimp P. semisulcatus by PCR. Agarose gel showing PCR amplification using nested PCR primers. (A) Lane M: Molecular weight marker (I 00 bp); Lane I: positive control; Lanes 2-I2 control shrimp (healthy shrimp): Lane I3: Negative control. (B) Lane M: Molecular weight marker (I00 bp); Lanes I-2: Negative control; lane 3: positive control; lanes 4-I0 healthy shrimp at harvest (60 days of culture).

\section{Discussion}

Farm observations showed that shrimp infected with IHHNV/ PstDV-1 show slow growth rate and rostrum deformity, which called as runt-deformity syndrome..$^{14}$ All such external symptoms of IHHNV/ PstDV-1 infection were observed in this study. A higher load of IHHNV/PstDV-1 compared to WSSV was observed. Early harvesting of shrimp at an early culture period (maximum 72 days, Table 1) to avoid crop loss. Previous studies showed that, the effect of IHHNV has been described to be chronic, ${ }^{13,15}$ and this is not in line with the present results where was not possible to culture the shrimp for long period and thus harvested early due to the appearance of the symptoms. The farm observation showed that $P$. semisulcatus has been reported to be sensitive to IHHNV/PstDV-1 infection with severe mortalities due to IHHNV/PstDV-1 infection. This indicates the risk associated with the wild stocks as a reason for IHHNV/PstDV-1 outbreaks. 
Large number of samples $(85.47 \%)$ analysed were found to be positive for IHHNV/PstDV-1 in the first-step PCR indicating heavy IHHNV viral load. Low prevalence of WSSV infection (14.53\%) in cultured $P$. semisulcatus samples from DTZ, Egypt, where the shrimp was apparently healthy without any signs of disease. There is evidence in the literature showed that mortality of shrimp due to IHHNV/ PstDV-1 infection alone has been reported in P. stylirostris shrimp. ${ }^{4,5}$ In grow-out ponds, multiple viral infections of IHHNV/PstDV-1 and WSSV are commonly found. However, the present study on $P$. semisulcatus indicating IHHNV/PstDV-1 to be the sole agent causing mortality is also available and in line with a previous study reported heavy mortality of $P$. monodon due to IHHNV/PstDV-1 infection. ${ }^{16}$ More information on genetic variation associated with the virulence or any other factors responsible to bring such kinds of mass mortality are however necessary to confirm such incidences.

Prevalence of IHHNV/PstDV-1 infection was high in all farms surveyed, suggesting a widespread distribution of the virus in DTZ region. The virus transmitted horizontally through cannibalism, contaminated water, carriers, or vertically from broodstock that pass the virus to their progeny. ${ }^{17,6}$ In Egypt, wild-caught $P$. semisulcatus broodstock are the only source of spawners in hatcheries. Screening of broodstock for viral infections is not a routine practice in Egyptian hatcheries, allowing viral transmission and the contamination of aquaculture facilities. Thus, the high prevalence of IHHNV/ PstDV-1 infection in all grow-out ponds may be due to using wild $P$. semisulcatus broodstock naturally infected with the virus or to other wild crustaceans entering the shrimp ponds during culture. Therefore, the high prevalence of IHHNV/PstDV-1 in juvenile shrimp in growout ponds could be a consequence of low awareness regarding viral screening in hatcheries, meaning that shrimp seed released for stocking would carry a high potential risk of being infected by multiple viral infections contracted in the hatchery. This study also confirmed that $\mathrm{IHHNV} /$ PstDV-1 is prevalent in Egypt, and in line with a similar case of viral infection in Indian hatcheries. ${ }^{18}$

Comparison of prevalence of the virus infection between the normal and undersized shrimp showed statistically significant difference $(\mathrm{p}<0.05)$. IHHNV/PstDV-1 is known to be highly pathogenic causing mass mortality in L. stylirostris; it has been implicated in stunted growth and runt deformity syndrome in L. vannamei $i^{13,19}$ as well as slow growth syndrome in $P$. monodon..$^{12}$ In the present study, although the prevalence of IHHNV/PstDV-1 in reduced growth shrimp was more than $80 \%$ while the prevalence in the normal growth shrimp was about $15 \%$, this difference was not statistically significant $(p>0.05)$.

Most farmers in DTZ region, the main area of shrimp production in Egypt, have switched from P. semisulcatus to L. vannamei due to shortage of high quality $P$. semisulcatus broodstock and seeds, low growth and high mortality. However, some farmers have remained faithful to $P$. semisulcatus although cultivation of $L$. vannamei has begun since 2014. As shrimp hatcheries have experienced difficulties in obtaining high quality broodstock, the quality of seed produced has tended to decline; efforts to raise quality broodstock from hatcheryproduced seed have not been successful to date. One possible solution to overcome this problem might be to catch broodstock from areas far from shrimp aquaculture activities, then properly screen them for viruses before use in breeding programs. The present study highlights the importance of the sustainability of P.semisulcatus culture in Egypt. The current situation of using wild stock without viral screening used for culture practice, still susceptible to the existing virulent viruses that can bring mortality and loss to shrimp farmers. Therefore, this study recommends strict biosecurity measures are necessary to prevent the shrimp from such kinds of infection to make shrimp farming sustainable.

\section{Conclusion}

PstDV-1 commonly occurs in cultured P. semisulcatus in DTZ, Egypt. P. semisulcatus sampled were infected by IHHNV/PstDV-1. These findings indicated that infectious IHHNV/PstDV-1 is prevalent in cultured shrimp in Egyptian aquaculture. The implementation of biosecurity in hatcheries and grow-out ponds, including the routine testing of broodstock and seed for presence of viral agents, will help reduce the spread of viral infections within and between Egyptian shrimp farming facilities.

\section{Conflicts of interest}

The authors declare that there are no conflicts of interest.

\section{Acknowledgement and funding}

This work was supported by Science \& Technology Development Fund (STDF), Egypt under grants no 5661.

\section{References}

1. Fauquet C, Mayo MA, Maniloff J, et al. Virus Taxonomy: Eighth Report of the International Committee on Taxonomy of Viruses. The viruses. 2005;988-992.

2. Shike H, Dhar, AK, Burns JC, et al. Infectious hypodermal and hematopoietic necrosis virus of shrimp is related to mosquito brevidensoviruses. Virology. 2000;277 (1):167-177.

3. Rai P, Safeena MP, Karunasagar I, et al. Complete nucleic acid sequence of Penaeus stylirostris densovirus (PstDNV) from India. Virus Research 2011;158:37-45.

4. Lightner DV, Redman RM, Bell TA, et al. Detection of IHHN virus in Penaeus stylirostris and P. vannamei imported into Hawaii. Journal of the World Mariculture Society. 1983;14 (1-4):212-225.

5. Lightner DV, Redman RM, Bell TA. Infectious hypodermal and hematopoietic necrosis, a newly recognized virus disease of penaeid shrimp. Journal of Invertebrate Pathology.1983;42(1):62-70.

6. Lightner D.V. Virus diseases of farmed shrimp in Western Hemisphere (the Americas): A review. J Invert Pat. 2011;106(1):110-130.

7. Vega-Heredia S, Mendoza-Cano F, Sanchez-Paz A. The infectious hypodermal and haematopoietic necrosis virus: a brief review of what we do and do not know. Transboundary and Emerging Diseases.2012;59 (2):95-105.

8. Teixeira-Lopes MA, Vieira-Girao PRN, Freire JEC, et al. Natural coinfection with infectious hypodermal and hematopoietic necrosis virus (IHHNV) and infectious myonecrosis virus (IMNV) in Litopenaeus vannamei in Brazil. Aquaculture. 2011; 312:212-216.

9. Tang KFJ, Poulos BT, Wang J, et al. Geographic variations among infectious hypodermal and hematopoietic necrosis virus (IHHNV) isolates and characteristics of their infection. Dis Aquat Organ.2003;53(2):91-99.

10. Krabsetsve K, Cullen BR, Owens L. Rediscovery of the Australian strain of infectious hypodermal and haematopoietic necrosis virus. Diseases of Aquatic Organisms. 2004;61 (1-2):153-158. 
11. Tang KFJ, Lightner DV. Infectious hypodermal and hematopoietic necrosis virus (IHHNV)-related sequence in the genome of the black tiger prawn Penaeus monodon from Africa and Australia. Virus Research 2006;118(1-2):185-191.

12. Rai P, Pradeep B, Karunasagar I. Detection of viruses in Penaeus monodon from India showing signs of slow growth syndrome. Aquaculture. 2009;289(3-4):231-235.

13. Bell TA, Lightner DV. IHHN virus: infectivity and pathogenicity studies in Penaeus vannamei. Aquaculture.1984;38 (3):185-194.

14. Kalagayan H, Godin D, Kanna R, et al. IHHN virus as an etiological factor in runt-deformity syndrome (RDS) of juvenile Penaeus vannamei cultured in Hawaii. Journal of the World Aquaculture Society. 1991;22:235-243.

15. Primavera JH, Quinitio ET. Runt-deformity syndrome in cultured giant tiger prawn Penaeus monodon. J Crustac Biol. 2000;20 (4):796-802.
16. Sheela RR, Muralimanohar B, Sundarraj A, et al. Infectious hypodermal and haematopoietic necrosis virus (IHHNV) in cultured Penaeus monodon in Tamil Nadu. India J Fish. 1998;45:183-186.

17. Withyachumnarnkul B, Chayaburakul K, Lao-Aroon S, et al. Low impact of infectious hypodermal and hematopoietic necrosis virus (IHHNV) on growth and reproductive performance of Penaeus monodon. Diseases of Aquatic Organisms. 2006;69 (2-3):129-136.

18. Joseph TC, James R, Anbu Rajan L, et al. Occurrence of viral pathogens in Penaeus monodon post-larvae from aquaculture hatcheries. Data in Brief. 2015;4:170-176.

19. Gunalan B, Soundarapandian P, Anand T, et al. Disease occurrence in Litopenaeus vannamei shrimp culture systems in different geographical regions of India. International Journal of Aquaculture. 2014;4(4):24-28. 